$11-1989$

\title{
A Typology of Suburban Economic Development Policy Orientations
}

John P. Pelissero

Loyola University Chicago, jpeliss@luc.edu

David Fasenfest

University of Louisville

Follow this and additional works at: https://ecommons.luc.edu/politicalscience_facpubs

Part of the Political Science Commons

\section{Recommended Citation}

Pelissero, John P. and David Fasenfest, "A Typology of Suburban Economic Development Policy Orientations," Economic Development Quarterly Vol. 3 (November 1989): 301-311.

This Article is brought to you for free and open access by the Faculty Publications and Other Works by Department at Loyola eCommons. It has been accepted for inclusion in Political Science: Faculty Publications and Other Works by an authorized administrator of Loyola eCommons. For more information, please contact ecommons@luc.edu. (c) (1) $\Theta$

This work is licensed under a Creative Commons Attribution-Noncommercial-No Derivative Works 3.0 License. 


\section{A Typology of Suburban Economic Development Policy Orientations}

\author{
John P. Pelissero \\ Loyola University of Chicago \\ David Fasenfest \\ University of Louisville
}

\begin{abstract}
This article explores variations in economic development goals and orientations among suburban governments and the impact of these on economic development programs. The research was conducted among suburban officials in the Chicago Metropolitan area who responded to a survey in 1987. The results of the survey show that suburbs can be divided into five types based upon their economic development policies: aggressive, regulatory, cooperative, retentive, and reactive. These general policy orientations were found to affect the specific city government staffing, planning, activities, fiscal programs, and regulation related to economic development in the community.
\end{abstract}

Developing the economic base of urban areas remains one of the top issues of the late $1980 \mathrm{~s}$. Indeed, city upon city is found searching for new ways to retain the existing industrial base, diversify the economy, keep current retailers satisfied, and attract new businesses and industries to the jurisdiction. Often this search is a zero sum game, pitting one city against another, with only one winner in the battle for economic development. Such intense competition is more apparent in our large, fragmented metropolitan areas. Much of the research on urban economic development has focused on central city policies and problems, ', industrial decisions regarding urban location, ${ }^{2}$ and successful state/local strategies for attracting industry and expanding the labor force. ${ }^{3}$ Study of economic development by local governments within a shared metropolitan political economy is not found. Yet this is an area appropriate for examination of several important questions on development. This article seeks to aid our understanding of intrametropolitan economic development policies. The purpose of this research is to explore variations in economic development policy orientations and their impact on the adoption of suburban development policies. The article reports the results of a survey of 105 suburbs in the Chicago metropolitan area.

\section{COMMUNITY DEVELOPMENT ORIENTATIONS: A REVIEW}

Within any community, the objectives of economic development policies are essentially the same: (1) to expand the community's tax base, (2) to maintain and attract commercial and industrial investment in the community, (3) to create and retain employment opportunities for community residents, and (4) to foster the image of a stable or growing community that will be attractive to residents, businesses, investors, and lenders. In order to meet these objectives, communities pursue a varied set of development strategies, including publicly subsidized industrial sites, tax abate-

\begin{abstract}
John P. Pelissero is Associate Professor of Political Science at Loyola University of Chicago. He has published widely on urban politics and policy, and is currently studying the impact of professional sports franchises on municipal economic development policies.
\end{abstract}

David Fasenfest is currently Director of Economic Development Research at the Urban Studies Center, University of Louisville. Formerly with Loyola University of Chicago, he has conducted research on a variety of economic development projects, including Detroit's Poletown, enterprise zones, and Chicago's changing industrial policy.

AUTHORS' NOTE: We would like to thank Christopher Beem, who conducted preliminary interviews for this research, and Jing Zhang, who handled the data entry. 
The appearance of only a modest volume of research on suburban economic development and development policies may be linked to the common notion that suburbia, in general, is far better off than central city areas and has not been forced to consider action programs for redevelopment and revitalization as have many declining central cities. ments and exemptions, low interest loans, infrastructure improvements (e.g., water systems, streets), industrial parks, and even advertising campaigns. ${ }^{4}$

Much of the research on urban economic development has focused on large central cities. Few research projects have considered the economic development orientations and policies within a metropolitan area. ${ }^{5}$ But when one examines metropolitan America, urban development is generally found to be uneven across cities. ${ }^{6}$ The metropolitan political economy can produce advantages and disadvantages to development for any city, including the suburbs. ${ }^{7}$ If one accepts Paul Peterson's thesis in City Limits ${ }^{8}$ that development policies are of primary interest to a city, then local policymakers must strive to find ways to offset community disadvantages while stimulating advantages in the community.

Public choice theorists contend that suburban areas foster healthy market conditions for competition of divergent policies related to development. ${ }^{9}$ The variety of development programs in a city, like other policies and services, presents the potential business or industrial client with a smorgasbord of options that, following the Tiebout theory, ${ }^{10}$ ultimately produce efficiency in community tax and service policies. But uneven development and competitive policies can lead to inefficiencies in suburban economic development strategies, ${ }^{11}$ forcing some suburban governments to become more aggressive just to maintain their tax or employment base.

The appearance of only a modest volume of research on suburban economic development ${ }^{12}$ and development policies may be linked to the common notion that suburbia, in general, is far better off than central city areas and has not been forced to consider action programs for redevelopment and revitalization as have many declining central cities. Indeed, if $75 \%$ of all manufacturing employment (as of 1980) is located outside of central cities, including $42 \%$ in the suburbs, ${ }^{13}$ and most major new retail malls in metropolitan areas are found in suburbs ${ }^{14}$ and suburbs are the preferred location of newer service and high technology industries, ${ }^{15}$ why focus upon suburbs rather than central cities in this policy area? The reason is precisely because there are significant differences among suburbs and some important similarities in the condition of central cities when it comes to economic development.

A framework for the study of suburbs can be gleaned from the extant literature on communities. ${ }^{16} \mathrm{~A}$ review of this literature suggests that there are three distinct types of communities, in addition to the central city, in which the residents and leaders can be expected to hold different orientations toward economic development.

(1) Aging Developed. Older suburbs in the inner ring near the central city have been shown to be afflicted by many of the same problems as their older central cities. Fernandez and Pincus point out that, like the central city, older suburbs are suffering "a general decline in population, demographic change, fiscal pressure, stagnating income, and a variety of social problems." ${ }^{17} \mathrm{We}$ hypothesize that these suburbs will have the most aggressive economic development policies and that the policies will be designed to meet the competition from newer suburbs.

(2) Established Developed. A second group of suburbs are essentially fully developed, though not as old as those in the inner ring, and are most concerned with stability in their established economic base. While the older suburbs are likely to pursue economic development with aggressive policies, we would expect the stable, developed suburbs to pursue policies that promote retention of existing commercial interests and caution with any proposed expansion or change in the community's economic activities. ${ }^{18}$

(3) Growing Developing. The third group of suburbs can be classified based upon growth in developable residential and nonresidential land and continuing development of the economic base. They may be newer suburbs or they may have been established years ago but still have large areas of undeveloped land. Because of the availability of commercial land, we anticipate that these suburbs normally do not have to adopt any economic development strategies. Rather, these suburbs pursue development in a planned, logical fashion, with significant regulation of all proposed development. This latter group tends to be the most economically secure among suburban communities. The developing suburbs are likely to be the least engaged in developing competitive policies because of their sound economic base that is still enlarging without any formal stimulation by the city government.

In this article we assume that suburban cities within the same metropolitan political economy must contend not only with market forces, but also with the strategic development policies of the 
central city and, more important, the surrounding suburbs. Hence, any suburban city's development policies are likely to be stimulated by the city's own development needs and the state of the private market, and also by what is being done by the public policy makers in neighboring competitive jurisdictions. John Levy has aptly described the intense competition for new industries that takes place among cities. "The firm known to be contemplating a move, or even the firm which simply looks as though it would be a good addition to the local economy and tax base, is often besieged by suitors." ${ }^{19}$ This article seeks to examine the nature of economic development policy orientations among suburbs in a common political economy.

\section{RESEARCH DESIGN}

The aforementioned literature suggests that communities vary in their level of development and stability, and further, that within a metropolitan area suburbs are in competition for development. Because of this situation we expect that each community will attempt to structure their development policies to some strategic advantage. Our basic hypothesis can be stated as follows:

Suburban communities within the same metropolitan political economy will pursue economic development dependent upon community need and competition.

This hypothesis can be further refined this way:

Suburban government officials' orientations toward, and policies for, economic development will vary depending upon their perceptions of the community's development orientations, needs, and the development policies of neighboring governments.

To assess the linkages between types of suburbs, development orientations and policies, and perceived or actual intraregional competition, we sent surveys to all 261 suburbs in the Chicago metropolitan area in August 1987. The suburbs are in six Illinois counties: Cook (the largest), DuPage, Kane, Lake, McHenry, and Will. ${ }^{20}$ Responses were received from 105 communities, or $40 \%$.

A survey was developed to address development orientations and policies in the Chicago metropolitan area. Initially, the survey was pretested on a group of city managers, mayors, and development directors in 23 Chicago suburbs. The pretest was either telephone or personal interview. ${ }^{21}$ From the data gathered in the pretest, and the valuable suggestions of these officials, the final survey was constructed and mailed to the suburbs addressed here.

The survey included both open and closed end questions. The questionnaire requested information about the city's economic development staff and their activities. We asked each respondent to describe the city council's general policy on attracting and retaining economic development activities. A series of closed-end questions explored the range of economic development activities, policies, plans, fiscal incentives, and regulations related to economic development. The final part of the survey asked about development in relation to other communities and the impact of neighboring governments' policies on policy in the respondent's community.

The responses brought us a good mixture of old and new suburbs. In general, these suburbs share a common political economy that tends to be defined by their proximity to (or from) Chicago, their distance to the major interstate highways, and the availability of developable land in this region.

\section{FINDINGS}

Generally, the responses came from the publicly elected or appointed official in each suburb that had the major responsibility for development policy. The 105 respondents included city managers $(36 \%)$, mayors/presidents $(21 \%)$, economic development directors/department heads (15\%), city clerks $(9 \%)$, planners (7\%), assistant city managers $(6 \%)$, community development directors (3\%), city council members (who usually chaired a committee on development) (3\%), and a finance director $(1 \%)$. 
Older suburbs seem to pursue development aggressively in order to maintain the job market and expand or maintain the fiscal base. But newer, more prosperous suburbs are aggressively pursuing development also. In the latter case, the motivation appears to be largely related to fiscal expansion considerations and not job market concerns.

\section{Bolicy Orientations}

To understand the variation in development policies and programs in suburbia, we believed that the most important question to ask was about "the city council's general policy on attracting and retaining economic development activities." The open-ended responses to this question and our subsequent analysis of all other answers permitted us to arrive at a classification of development policy orientations in these suburbs. This classification yields a typology of suburbs on development policy.

Table 1 shows the classification that resulted from our analysis of the responses to the "general policy" questions and the subsequent review of other responses to policy-related questions. In a few cases we found that the respondent had misrepresented or overstated the general policy. Our decisions about the actual policy arientation of the communities is shown in Table 1 . We have displayed the orientations from most aggressive on development to antidevelopment. As shown in the table, $23(22 \%)$ suburbs follow a general policy on economic development that can be labeled "aggressive." These communities are very proactive and competitive in seeking development of business or industrial activities. Councils have adopted a variety of aggressive marketing strategies and have approved competitive fiscal and service policies to attract investment in the community. A few of these communities followed general policies that placed some limits on the proactive approach to gaining or retaining development, such as only seeking retail development or following aggressive policies for limited geographic or economic sections of the community. Intense competition for economic development is perceived by these suburbs' leaders. Older suburbs seem to pursue development aggressively in order to maintain the job market and expand or maintain the fiscal base. But newer, more prosperous suburbs are aggressively pursuing development also. In the latter case, the motivation appears to be largely related to fiscal expansion considerations and not job market concerns. ${ }^{22}$

A second set of communities can be classified as "regulatory." These 13 communities do not find it necessary actively to seek economic development. Because of the amount of developable land in the suburb, they have the advantage of being able to wait for developers to come to them. Furthermore, because of the attractive nature of their community, rather than making concessions to stimulate development, they make demands of potential developers. They have significant regulation of economic development, including an extensive array of fees and codes that must be paid or met by each developer. Adherence to regulations that are believed to be in the public interest is considered more important than development per se.

In all, 19 cities followed a general policy on development that is best described as "cooperative." These communities follow policies that include moderately prodevelopment values. The council has normally approved a limited range of economic development policies designed to create a positive environment for business or industrial clients. In general, an aggressive development stance is inconsistent with these relatively stable, established communities' values which often promote the integrity of quality single-family dwellings. But a cooperative spirit helps to promote stability and a gradual expansion in the economic development activity portion of the tax base.

A city council that is not promoting new business or industrial activity in the community may value retention of the existing economic base above any new development. Indeed, 13 communities, many old, stable suburbs that are a mixture ${ }^{23}$ of both residential and commercial components, fell into this category. "Retentive" suburbs have adopted an extensive list of development policies, but their strategy is to target these policies at existing businesses and industries that may need some assistance or incentive to remain in the community. ${ }^{24}$ Maintaining the retail outlets in the older downtowns often in competition with retail malls, is a common concern of policymakers in this type of suburb. In a sense, this business base in a retaining suburb faces the same threats as the central business districts (CBD) in many older central cities - declining physical plants, restricted space for expansion, less shopper traffic, and limited parking. While this suburban type senses competition from newer suburbs that have more space available or attractive indoor retail malls, they have adopted a goal of stabilizing the present retail community rather than considering any possible expansion. Policies tend to be developed that will improve the attractiveness of existing retail areas for both businesses and customers. Generally, the strategy is to maintain the status quo. Two forces seem to govern a retentive suburb's approach to industrial activity. First, the com- 
TABLE I

City Council Policy Orientations on Economic Development

\begin{tabular}{lcc}
\hline Policy Orientation & Number & Percentage \\
\hline Aggressive & 23 & 21.9 \\
Regulatory & 13 & 12.4 \\
Cooperative & 19 & 18.1 \\
Retentive & 13 & 12.4 \\
Reactive & 27 & 25.7 \\
Antidevelopment & 1 & 0.9 \\
Unknown/Missing Data & 9 & 8.6 \\
\multicolumn{1}{c}{ Total } & 105 & 100 \\
\hline
\end{tabular}

munity has become comfortable with the present activities that are not a threat to the residential community's quality of life. Second, because of limited undeveloped land, it is unlikely that the community could attract new industry even if it tried.

Slightly more than one fourth of the cities in our study follow no formal policy on economic development. Although a few have policies that address economic development issues, these cities tend to react as development issues arise. Generally, these "reactive" communities are developed suburbs. The only value of policymakers that seems apparent is laissez-faire. If economic activities want to locate in their community, fine; if others choose to leave the community, that might be fine, too. As long as economic development change does not present a significant threat to the tax base or quality of residential life, the orientation of policymakers is to remain uninvolved observers. However, policymakers do take action when necessary: when the possible loss of business or industry could seriously affect the tax base, or when the proposed establishment of a new development poses a threat to the quality of life or quality of service delivery. Hence, when no general policy on economic development is considered necessary, these communities will react to possible change with specific policies on a case-by-case basis.

The value orientations of the local councils have shaped the particular mix of policies followed in each suburb and have determined the community government's competitive or cooperative approach to development within the region. At least one suburban official indicated that the community and its council were decidedly "antidevelopment." The remaining communities did not provide an answer to the question about general policy or enough other information in the questionnaire for us to accurately classify their policy orientation. But in the 95 suburbs for which we have complete data, we are able to explore in more detail the nature of policies in use.

\section{Institutional Capacity}

Table 2 displays information about the capacity to implement economic development policy in each of the five types of suburbs. Overall, just one third have an economic development plan (or something like it as part of the city's comprehensive plan) approved by the council. Aggressive policy suburbs have the highest ratio (52\%) of economic development plans whereas retentive suburbs have the smallest adoption ratio (15\%). Also, between one and three suburbs of each policy orientation had a growth policy to control development; however, none of the reactive suburbs had used it. Another measure of a community's capacity to implement policy is having a department and staff designated for economic development. Roughly half of aggressive and retentive suburbs had a department for economic development. The lowest ratio (18\%) of suburbs with a designated department was found among those classified as reactive on economic development matters. Related to this item is the number of staff, who is from a line or staff department or is a member of the chief executive's office, who work on economic development matters. It may be interesting to note that, as shown in Table 2, the average number of staff is not closely related to the character of the general policy. Suburbs with cooperative policy orientations had the 
TABLE 2

Capacity for Economic Development Policy Implementation

\begin{tabular}{lcccc}
\hline Policy Orientation & Total & $\begin{array}{c}\text { Economic Development } \\
\text { Plan (percent) }\end{array}$ & $\begin{array}{c}\text { Department } \\
\text { (percent) }\end{array}$ & Average Staff \\
\hline Aggressive & 23 & 52 & 48 & 3 \\
Regulatory & 13 & 31 & 31 & 3.25 \\
Cooperative & 19 & 26 & 37 & 4 \\
Retentive & 13 & 15 & 54 & 1.5 \\
Reactive & 27 & 26 & 18 & 2 \\
\multicolumn{1}{c}{ Total } & 95 & 32 & 36 & - \\
\hline
\end{tabular}

highest average staff, whereas the retentive suburbs used the least. And, on average, aggressive suburbs used only one more staff than the group following the least aggressive policy - the reactive policy suburbs.

Overall, the more aggressive the policy orientation, the wider the adoption of an economic development plan and the greater the frequency of staff and departments for development.

\section{Economic Development Activities}

Table 3 shows four sets of activities related to furthering economic development in which a community may be involved. Profile refers to maintenance of either demographic, economic, or tax rate/burden information about the community by the city government. This profile information is used to help "sell" the community to prospective businesses or industries that are considering locating in that suburb. ${ }^{25}$ In all, $72 \%$ of suburbs maintain profiles. The use of profiles ranges from a high of $91 \%$ among aggressive policy suburbs to $56 \%$ in reactive policy suburbs. Again, the more aggressive the orientation, the more active the suburb in encouraging development. Coordinate refers to city government activities, such as having a liaison/ombudsman office with business and industry ${ }^{26}$ or working with a quasipublic development agency. Cities that engage in this activity believe it is necessary to coordinate economic development objectives with the private sector in a regular or formal way. ${ }^{27}$ Only $48 \%$ of suburbs in our survey engage in coordinating activities. The ratio is somewhat higher than this among the aggressive policy suburbs (57\%); it runs slightly lower in suburbs with cooperative $(47 \%)$ and reactive $(41 \%)$ policy orientations. In general, those communities trying to keep their existing economic base or significantly expand it are more likely to adopt coordinative policy.

Another set of actions is concerned with preserving the departing businesses and industries in

We found $67 \%$ of suburbs to be engaged in regular contacts with businesses to ensure that they do not relocate without the city having had an opportunity to offer them an incentive to remain. the community. We found $67 \%$ of suburbs to be engaged in regular contacts with businesses to ensure that they do not relocate without the city having had an opportunity to offer them an incentive to remain. Some cities have even adopted a formal policy on "business retention," or a key public official has assumed the responsibility of working actively with businesses. In some cases the mayor, village president, or city manager has adopted a proactive role in working to keep existing businesses or industries in the community - a key variable for success found in many studies of central city redevelopment. ${ }^{28}$ In about one fifth of the suburbs, the city now owns buildings for lease to businesses, especially those needing an incentive to stay in the community. Again (Table 3), the aggressive policy suburbs are making the most use of this activity (83\%), whereas just under half $(48 \%)$ of reactive policy suburbs have found it necessary to act on preservation of the existing business base. Somewhat surprising is the finding that retentive suburbs are only about average among cities doing preservation. The finding suggests a breakdown between plan and action in the retentive policy communities. The last broad activity receiving wider use in suburbs is self-promotion of various kinds. The most common forms were government-sponsored advertisements in magazines or newspapers, press releases designed to create more awareness of development opportunities, and the use of the Chamber of Commerce and other local promotion agencies to sell the city, often providing city funding to the chamber to aid the local promotion effort. Overall, $77 \%$ of suburbs in our study engage in promotion. This includes $100 \%$ of the 
TABLE 3

Economic Development Activities in Suburbs

\begin{tabular}{lllccc}
\hline Policy Orientation & $\begin{array}{c}\text { Total } \\
(N)\end{array}$ & $\begin{array}{c}\text { Profile } \\
\text { (percent) }\end{array}$ & $\begin{array}{c}\text { Coordinate } \\
\text { (percent) }\end{array}$ & $\begin{array}{c}\text { Preserve } \\
\text { (percent) }\end{array}$ & $\begin{array}{c}\text { Promote } \\
\text { (percent) }\end{array}$ \\
\hline Aggressive & 23 & 91 & 57 & 83 & 100 \\
Regulatory & 13 & 77 & 46 & 69 & 62 \\
Cooperative & 19 & 68 & 47 & 74 & 74 \\
Retentive & 13 & 69 & 54 & 69 & 69 \\
Reactive & 27 & 56 & 41 & 48 & 70 \\
\multicolumn{1}{c}{ Total } & 95 & 72 & 48 & 67 & 77 \\
\hline
\end{tabular}

aggressive policy suburbs, followed by suburbs with cooperative (74\%), reactive (70\%), retentive $(69 \%)$, and regulatory $(62 \%)$ policy orientations. Finding that regulatory suburbs are less likely to be engaged in promotion is not surprising. These suburbs are well known, attractive locales for developers and they can afford to be less aggressive because business and industry regularly pursue them.

\section{Fiscal Policies}

Perhaps best known among the activities that communities engage in when shopping for economic development are fiscal policies, especially tax breaks. Tax rates and levels are a major concern of economic interest, ${ }^{29}$ and many communities have sought to create a competitive edge. As shown in Table 3, most local governments maintain a ready tax burden profile showing how favorably the suburb compares with surrounding communities. Table 4 shows the use of tax incentives, loans, capital budgeting, and services underwriting by the Chicago suburbs. The most widely used fiscal policy was some type of tax break for economic development. In our survey $54 \%$ of suburbs offered tax abatements and/or tax-exempt financing through Industrial Revenue Bonds (IRB) for development. Again, we find the aggressive policy communities being significantly ahead of others in the use of tax incentives ( $83 \%$ ), and nearly two-thirds of regulatory policy suburbs are also offering them. These higher policy adoption rates contrast with a $33 \%$ usage rate in the reactive policy suburbs.

The next most widely used fiscal policy for economic development is a loan program. The actual form of the program varies across communities, and we were able to identify five different features of loan incentives for development: (a) city government guarantees of loans for the private sector, (b) city government providing below-market interest rate financing for development, (c) interest rate reductions in which the city pays part of the normal interest charges to a lender on behalf of a borrower, (d) leveraging economic development with Community Development Block Grant funds, and (e) financing economic development through the sale of general obligation (GO) bonds.

Some cities' loan programs included all of the foregoing, though it was more common for loan programs to encompass a smaller set of options. Table 4 shows that, overall, $42 \%$ of Chicago suburbs have a loan program. Over half of aggressive policy suburbs have loan programs, while fewer than half of the other policy type suburbs have them. In fact, only one-third of reactive policy cities and a mere $23 \%$ of retentive policy communities have adopted these programs.

Another way to encourage economic development is to use the city budget directly to finance or underwrite some private sector development. For example, $30 \%$ of responding suburban officials in Table 4 told us that their community uses the capital budget to finance major economic development projects. Although only a handful of regulatory (15\%), retentive (23\%), and reactive $(19 \%)$ policy suburbs have adopted such a program, nearly one-third of cooperative policy communities have approved such financing and more than one-half $(57 \%)$ of aggressive policy suburbs have done the same. Some of these suburbs also pay for city services needed by industry. Of suburbs in Table 4, 30\% have adopted policies under which the city pays for improvements in water distribution systems, waste treatment, or transportation systems in order to attract develop- 
TABLE 4

Fiscal and Tax Polices for Economic Development

\begin{tabular}{lccccc}
\hline Policy Orientation & $\begin{array}{c}\text { Total } \\
(N)\end{array}$ & $\begin{array}{c}\text { Tax } \\
\text { Incentives } \\
\text { (percent) }\end{array}$ & $\begin{array}{c}\text { Loan } \\
\text { Program } \\
\text { (percent) }\end{array}$ & $\begin{array}{c}\text { Capital } \\
\text { Budget } \\
\text { (percent) }\end{array}$ & $\begin{array}{c}\text { Pay for } \\
\text { Services } \\
\text { (percent) }\end{array}$ \\
\hline Aggressive & 23 & 83 & 57 & 57 & 48 \\
Regulatory & 13 & 62 & 46 & 15 & 31 \\
Cooperative & 19 & 42 & 47 & 32 & 37 \\
Retentive & 13 & 54 & 23 & 23 & 23 \\
Reactive & 27 & 33 & 33 & 19 & 15 \\
\multicolumn{1}{c}{ Total } & 95 & 54 & 42 & 30 & 30 \\
\hline
\end{tabular}

ment. Adoption of such service underwriting policies is employed by $48 \%$ of aggressive policy suburbs but by $37 \%$ or less of the other suburbs. Indeed, only $15 \%$ of reactive policy suburbs do this and even then it was probably a response to a single case and not a general policy.

Overall, fiscal and tax policies are most often found among the policy adoptions of more aggressive policy communities.

\section{Land Use Policy}

A few minor programs are being used in these suburbs to attract development also. For instance, $42 \%$ of the Chicago suburbs have at least one industrial park and $7 \%$ of them are owned by the suburb. Zoning or land use plans in 58\% of the communities expressly reserve land for future industrial development. And in recent years land use controls and zoning policies have been changed in $39 \%$ of the suburbs in order "to attract more economic development."

\section{Competition}

Are the policies being adopted, plans being formulated, and programs being modified because of competition from other jurisdictions in the metropolitan political economy? We asked suburban officials about competition with other suburbs for the same developments. A great deal of competition was perceived by $39 \%$ of the suburbs, most of which had adopted policies to keep their communities competitive. Another 36\% experienced "some competition." Some $10 \%$ of Chicago suburban officials found very little competition from other suburbs, while $15 \%$ said that "no competition" existed. There was little variation across our typology on this question. Competition also turns out to be a better explanation than is diffusion for economic development policy adoption. ${ }^{30}$ Only 3 of 105 suburbs adopted an economic development policy from those successfully used by neighboring suburbs and only two suburbs had avoided a policy that had failed in another suburb. And as these suburban officials looked to the future, $94 \%$ believed that they would find "the same" or "more" competition in the next year.

\section{Regulation Versus Development}

As addressed here, at least one policy type apparent in suburbs is that of the regulator. The character of these suburbs seems to be one of close adherence to zoning, capital improvement plans, and development regulations. These suburbs assess fees for virtually every phase of the development process from the review of plans to utility connections to land dedications for parks, schools, or libraries.

We asked all suburban officials in the survey about the extent of regulation on economic development. The results are shown in Table 5. Initially, we wanted to know if a suburb could be described as one in which concern with regulating business and industrial development was of greater concern than finding ways to attract development. Overall, 53\% of responding officials indicated that this was the case. Table 5 shows (under "Regulation not Development") that all 
TABLE 5

Regulation of Economic Development

\begin{tabular}{lcccccccc}
\hline $\begin{array}{l}\text { Policy } \\
\text { Orientation }\end{array}$ & $\begin{array}{c}\text { Total } \\
(N)\end{array}$ & $\begin{array}{c}\text { Regulation } \\
\text { not Development } \\
(\text { percent })\end{array}$ & $\begin{array}{c}\text { Annex } \\
\text { Fee } \\
\text { (percent) }\end{array}$ & $\begin{array}{c}\text { Plan } \\
\text { Fee } \\
\text { (percent) }\end{array}$ & $\begin{array}{c}\text { Utility } \\
\text { Hook } \\
\text { (percent) }\end{array}$ & $\begin{array}{c}\text { Connect } \\
\text { Fee } \\
\text { (percent) })\end{array}$ & $\begin{array}{c}\text { Land } \\
\text { Ded } \\
\text { (percent) }\end{array}$ & $\begin{array}{c}\text { Service } \\
\text { Impact Fee } \\
\text { (percent) }\end{array}$ \\
\hline Aggressive & 23 & 30 & 22 & 35 & 39 & 30 & 4 & 0 \\
Regulatory & 13 & 100 & 69 & 92 & 92 & 85 & 54 & 31 \\
Cooperative & 19 & 47 & 21 & 32 & 47 & 58 & 16 & 21 \\
Retentive & 13 & 62 & 38 & 54 & 46 & 46 & 23 & 23 \\
Reactive & 27 & 48 & 22 & 44 & 48 & 52 & 30 & 7 \\
\multicolumn{1}{c}{ Total } & 95 & 53 & 31 & 47 & 52 & 52 & 23 & 14 \\
\hline
\end{tabular}

regulatory policy suburbs fall into this category compared to only $30 \%$ of the aggressive ones. Concern with regulation over development was also apparent in $47-48 \%$ of cooperative and reactive and $62 \%$ of retentive policy suburbs.

The types of regulation in use also provide some interesting contrasts. In every example of regulation, the largest ratio of suburbs employing it is found among the regulatory ones, while the smallest level of regulatory adoption is nearly always among the aggressive suburbs. For instance, although $69 \%$ of regulatory suburbs require developers to pay a fee for land annexation to the city, typically only about one-fifth of other suburbs have a similar policy. A total of $92 \%$ of regulators assess a fee for city review of development plans, yet only $32 \%$ of cooperative and $35 \%$ of aggressive policy suburbs require such fees. Nearly all regulatory suburbs require developers to install all utility lines to the point of the nearest city feeder line, and also require payment of a fee for the actual connection. Only about half of other suburbs have similar regulations, with the adoption rate between $30 \%$ and $39 \%$ in aggressive suburbs. More than half of regulatory policy communities require the dedication of land or payment of a fee for future parks, schools, or libraries; a mere $4 \%$ of aggressive policy suburbs have a land dedication policy. Finally, while $31 \%$ of regulators make developers pay a "services impact fee" during the time of construction, none of the aggressive suburbs do this. The wide adoption of regulation is clearly paramount among our regulatory suburbs. The policy orientation of these suburbs can be described as "Here is what you must do to locate here" rather than "What can we do to get you to locate here?" which is dominant in more aggressive suburbs.

\section{DISCUSSION}

This article has presented a descriptive analysis of the urban economic development policy orientations in the suburbs of a major metropolitan area. The suburban government officials in this shared metropolitan political economy experience some of the same problems as do the central cities of this country. Each community has assessed its need or desire for further expansion or retention of the economic base in light of community orientations and the perceived level of competition around its borders.

The policy orientations on development matters in this sample fall into five general types. Aggressive policy suburbs have responded to development issues with the widest array of policy adoptions. Although only about half have put together a plan for economic development, they have among the best capacities for development, they are engaged in the most active forms of community promotion, and they have the most comprehensive set of fiscal and tax policy incentives for economic interests. Careful regulation of development is not a top priority, however. In many ways the aggressive suburbs act like central cities in their pursuit of development; a key difference is their likely newer physical plant.

A second type of suburb also encourages development but with attention to regulations not incentives. These regulatory suburbs are attractive sites for development and they need not give much to get economic base expansion. A third group of suburbs was found to follow a cooperative 
approach to development policy: a gradual expansion of economic development but with careful attention to the maintenance of the community's current character. Most of these are engaged in community promotion, and more than one-third offer fiscal policy incentives to development concerns.

A fourth group of suburbs were found to be oriented toward care of current economic interests. Retaining the present economic base with tax incentives, downtown business cooperative efforts, and coordinated activities with the private sector were the norm. And finally, the largest number of suburbs had no general policy on development. They simply reacted in response to development issues as they arose. In most policy areas they followed the most limited approach, usually adopting economic development policies when a need arose.

Support for our hypothesis regarding the impact of orientations on policy adoptions was apparent in the survey. The more aggressive the general policy toward development, the more likely the adoption of specific economic development policies. In addition, with little variation across our typology, we found perceived competition to be an apparent stimulus for adopted policies. However, although the survey has given us a glimpse into the economic development world of the suburbs, we need to move beyond the descriptive approach presented in this article. Future analyses must examine the multivariate causes of suburban development policy adoptions. Specifically, the relative impact of orientation type compared to other community variables, such as size, economic/tax base, and form of government, among others, should be assessed. At this point, we believe that the survey has given us a better understanding of the types of suburbs when considering urban economic development questions.

\section{NOTES}

1. Bernard L. Berkowitz, "Economic Development Really Works: Baltimore, Maryland," in R. D. Bingham and J. P. Blair, eds., Urban Economic Development (Beverly Hills, CA: Sage, 1984); Benjamin Chinitz, Central City Economic Development. Cambridge, MA.: Abt Books, 1979; Claire L. Felbinger, "Economic Development or Economic Disaster?: Joliet, Illinois," in Bingham and Blair, Urban Economic Development; and Bryan D. Jones and Lynn W. Bachelor, "Local Policy Discretion and the Corporate Surplus," in Bingham and Blair, Urban Economic Development.

2. W. Warren McHone and Brian Rungeling, "The Metropolitan Area Location Decisions of Wholesale Trade Firms," Economic Development Quarterly 1 (November 1987): 343-351; Brian M. Moriarty, Industrial Location and Community Development (Chapel Hill, NC: University of North Carolina Press, 1980); Robert Premus, "Urban Growth and Technological Innovation," in Bingham and Blair, Urban Economic Development.

3. Andrew J. Aulde, The Effectiveness of State and Local Industrial Development Incentive Mechanisms (Ithaca, NY: Program in Urban and Regional Studies, Cornell University, 1980); Susan Fainstein et al. Restructuring the City (New York: Longman, 1983); Cheryl A. Farr, ed., Shaping the Local Economy (Washington, DC: International City Management Association, 1984.)

4. For examples of strategies, see Aulde, The Effectiveness of State and Local Industrial Development Incentive Mechanisms, 40-46; Bingham and Blair, Urban Economic Development; Farr, Shaping the Local Economy; International City Management Association, “Marketing Your Community," Public Management 68 (June 1986); and John M. Levy, Economic Development Programs for Cities, Counties, and Towns (New York: Praeger, 1981).

5. Therese J. McGuire, "Are Local Property Taxes Important in the Intrametropolitan Location Decisions of Firms? An Empirical Analysis of the Minneapolis-St. Paul Metropolitan Area." Journal of Urban Economics 18 (1985): 226-234; William B. Neenan and Marcus E. Ethridge, "Competition and Cooperation Among Localities," in Bingham and Blair, Urban Economic Development.

6. Fainstein et al., Restructuring the City; John R. Logan and Harvey L. Molotch, Urban Fortunes: The Political Economy of Place (Berkeley: University of California Press, 1987).

7. J. V. Henderson, "Theories of Group, Jurisdiction, and City Size," in Peter Mieszkowski and Mahlon Straszheim, eds., Current Issues in Urban Economics (Baltimore, MD: Johns Hopkins University Press, 1979), 235-269.

8. Chicago: University of Chicago Press, 1981.

9. Vincent Ostrom, Charles Tiebout, and Robert Warren, "The Organization of Government in Metropolitan Areas." American Political Science Review 55 (December 1961): 831-842; Robert Bish, The Public Economy of Metropolitan Areas (Chicago: Markham, 1971).

10. Charles M. Tiebout, “A Pure Theory of Local Expenditure.” Journal of Political Economy 64 (1956): 416-424.

11. Henderson, "Theories of Group, Jurisdiction, and City Size," 250.

12. Mark Schneider, "The Market for Local Economic Development: The Growth of Suburban Retail Trade, 1972-1982," Urban Affairs Quarterly 22 (September 1986): 24-41.

13. John H. Mollenkopf, The Contested City (Princeton, NJ: Princeton University Press, 1983), 38.

14. Urban Land Institute, "Revitalizing Downtown Retailing: Trends and Opportunities." in Farr, Shaping the Local Economy, 92. 
15. Premus, "Urban Growth and Technofogical Innovation," 51: Steve Kerch, "Suburban Corridors on a Roll in Today's Realty Development," Chicago Tribune, 2 November 1986.

16. Charles R. Adrian and Charles Press, Governing Urban America 4th ed. (New York: McGraw-Hill, 1972); Leo F. Schnore, "The Social and Economic Characteristics of American Suburbs." Sociological Quarterly 4 (Spring 1963): 122-134; Oliver P. Williams, Harold Herman, Charles S. Liebman, and Thomas R. Dye, Suburban Differences and Metropolitan Policies: A Philadelphia Story (Philadelphia: University of Pennsylvania Press, 1965); Robert C. Wood, Suburbia: Its People and Their Policies (Boston: Houghton Mifflin, 1958).

17. Judith Fernandez and John Pincus, Troubled Suburbs: An Exploratory Study (Santa Monica, CA: RAND, 1982), xiii.

18. Henderson, "Theories of Group, Jurisdiction, and City Size."

19. Levy, Economic Development Programs for Cities, Counties, and Towns, 12.

20. Excluded were three counties that are part of the Chicago Consolidated Metropolitan Statistical Area: Kenosha (Wisconsin), and Porter and Lake (Indiana).

21. John P. Pelissero, "Intrametropolitan Economic Development Policies: An Exploratory Look at Suburban Competition and Cooperation," paper presented at the Midwest Political Science Association Annual Meeting, Chicago, IL., April 10-12, 1986.

22. Levy, Economic Development Programs for Cities, Counties, and Towns, 5.

23. Schnore, "The Social and Economic Characteristics of American Suburbs."

24. Thomas J. Seymour, “A Practical Approach to Business Retention.” Public Management 67 (December 1985): 17.

25. International City Management Association, "Marketing Your Community."

26. Edward deLuca, "Organizing and Operating a Development Department," in Far,, Shaping the Local Economy, 56.

27. See Harvey Molotch, "The City as a Growth Machine: Toward a Political Economy of Place." American Journal of Sociology 82 (September 1976): 309-332.

28. See Fainstein et al., Restructuring the City; and David Sink, "The Political Role of City Managers in Economic Redevelopment Programs." State and Local Government Review (Winter 1983): 10-15.

29. McGuire, "Are Local Property Taxes Important in the Intrametropolitan Location Decisions of Firms? An Empirical Analysis of the Minneapolis-St. Paul Metropolitan Area"; Moriarty, Industrial Location and Community Development, 96-97; Premus, "Urban Growth and Technological Innovation," 48-52; Gregory H. Wassall and Daryl A. Hellman, "Financial Incentives to Industry and Urban Economic Development." Policy Studies Review 4 (May 1985): 626-639.

30. Richard D. Bingham, The Adoption of Innovation by Local Government (Lexington, MA: D. C. Heath, 1976); and Everett M. Rogers and F. Floyd Shoemaker, Communication of Innovations: A Cross-Cultural Approach, 2nd ed. (New York: Free Press, 1971). 